\title{
GCU
}

Glasgow Caledonian

University

University for the Common Good

\section{Citizen science to communicate about public health messages: the reach of a playful online survey on sitting time and physical activity}

De Cocker, Katrien; Chastin, Sebastien F.M.; De Bourdeaudhuij, Ilse; Imbo, Ineke; Stragier, Jeroen; Cardon, Greet

Published in:

Health Communication

DOI:

10.1080/10410236.2018.1433955

Publication date:

2019

Document Version

Author accepted manuscript

Link to publication in ResearchOnline

Citation for published version (Harvard):

De Cocker, K, Chastin, SFM, De Bourdeaudhuij, I, Imbo, I, Stragier, J \& Cardon, G 2019, 'Citizen science to communicate about public health messages: the reach of a playful online survey on sitting time and physical activity', Health Communication, vol. 34, no. 7, pp. 720-725. https://doi.org/10.1080/10410236.2018.1433955

\section{General rights}

Copyright and moral rights for the publications made accessible in the public portal are retained by the authors and/or other copyright owners and it is a condition of accessing publications that users recognise and abide by the legal requirements associated with these rights.

Take down policy

If you believe that this document breaches copyright please view our takedown policy at https://edshare.gcu.ac.uk/id/eprint/5179 for details of how to contact us. 
Running head: Online communication on health behaviors

Citizen science to communicate about public health messages:

The reach of a playful online survey on sitting time and physical activity

(accepted for publication in Health Communication - January 2018)

Katrien De Cocker

Department of Movement and Sports Sciences

Ghent University

+32926463 23; katrien.decocker@ugent.be

\author{
Sebastien F.M. Chastin \\ Institute for Applied Health Research \\ Glasgow Caledonian University \\ Ilse De Bourdeaudhuij \\ Department of Movement and Sports Sciences \\ Ghent University \\ Ineke Imbo \\ Department of Administrative Affairs \\ Ghent University \\ $\&$ \\ Greet Cardon \\ Department of Movement and Sports Sciences \\ Ghent University
}




\begin{abstract}
There is a lack of research on how to communicate public health guidelines. Citizen science (CS) has been an effective way to involve the public in research. This study analyses the reach of a well-established CS experiment, launched during an annual national science event, to understand if it could be used as communication strategy for public health issues. A short playful online survey contained tailored health-related messages associated to an 'animal totem' profile, based on the combination of sitting and physical activity levels (koala: high sitting, low activity; gorilla: high sitting, high activity; zebra: low sitting, low activity; bee: low sitting, high activity). Tweets, radio interviews, radio and online advertisements, press articles and a press conference were used to promote the CS experiment. Google Analytics and Facebook graph API (application programming interface) (use and spread of experiment) and descriptive statistics (attributes of adults completing the experiment) were used. A total of 6,246 adults completed the experiment, with a peak of views $(n=5,103)$ and completions $(n=1,209)$ a couple of days before the event. Completers were mostly female $(65.8 \%)$, on average 37.5 years old and had a healthy body mass index $\left(23.8 \mathrm{~kg} / \mathrm{m}^{2}\right)$. Nearly half $(46.4 \%)$ had the most beneficial profile ('bee'), $26.5 \%$ had the least healthy profile ('koala'). CS as part of a national science event is a good platform for health communication as 1 in 1,000 Flemish adults were reached. However, those completing the experiment were not representative of the general Flemish adult population and reported to be more physically active.
\end{abstract}

Keywords: mass communication, population, sedentary behavior, guidelines 


\section{Background}

The recipe for a healthy lifestyle is to engage in regular moderate-to-vigorous intensity physical activity (Haskell et al., 2007) and to minimize sedentary behavior (any waking activity characterized by an energy expenditure $\leq 1.5$ metabolic equivalents (METs) while being in a sitting or reclining posture) (Thorp, Owen, Neuhaus, \& Dunstan, 2011). Recent evidence showed that even if people meet the current physical activity recommendations (Haskell et al., 2007), there are significant health risks related to the time spent sitting in the remaining non-active hours (Thorp et al., 2011). Given the previously documented evidence, several governments (UK, USA, AUS, Belgium, France etc.) currently encourage a core dual public health message promoting physical activity and less sitting time. Still, while guidelines for physical activity are internationally available, large proportions (47-90\%) of adults are unaware of physical activity guidelines (Hunter, Tully, Donnelly, Stevenson, \& Kee, 2014; Kay, Carroll, Carlson, \& Fulton, 2014; LeBlanc et al., 2015). As the evidence concerning sitting and health is fairly new, the knowledge on this topic is expected and shown to be even lower (LeBlanc et al., 2015). The distinction between being physical inactivity and sitting is not clear and adults link sitting particularly with musculoskeletal health problems and not with health in general and chronic diseases (De Cocker et al., 2015). So despite recent increasing popular media interest in the topic of sedentary behavior, further communication to the public about important health-related behaviors, especially sedentary behavior, seems to be warranted.

In order to communicate the above mentioned health messages to large audiences, raise community awareness, inform and change attitudes towards health behaviors, mass media campaigns have been organized in the past (Leavy, Bull, Rosenberg, \& Bauman, 2011). Even though awareness raising and increasing knowledge is not sufficient to change behavior, it is nevertheless an important aspect of health promotion (McGuire, 2001). Previous mass 
communications were rather isolated, resulting in a low reach (Lankford et al., 2014).

Evidence shows that health communication campaigns have a greater impact when combined with other strategies, such as community events, compared to those that only use a single strategy (Robinson et al., 2014). This raises the question whether more integrated communication, for example coupled with a 'citizen science' event, would be more effective. There has been a significant growth of 'citizen science', i.e. public involvement in scientific research (Follett \& Strezov, 2015). Through citizen science very large audiences can be reached and engaged, also in public health (Den Broeder, Devilee, Van Oers, Schuit, \& Wagemakers, 2016). For example, the 'Galaxy Zoo' project (asking citizens to assist in classifying images of galaxies via a survey) reached 200,000 people the first 2 years, resulting in an involvement of 274 participants per day. Citizen science can be used for the collection of data, but can also aim to educate the public (Den Broeder et al., 2016). As a result, a citizen science approach seems ideally suited to deliver public health messages in a stealth way. However, the reach of communicating through this form of citizen science projects is not really studied before.

Therefore, a team of researchers examining health behaviors accepted the invitation of the coordinators of a yearly well-established scientific public event organized in Flanders (Belgium) to collaborate on the development of their yearly citizen science 'experiment'. In 2015, it was decided to focus the citizen science 'experiment' on communicating about health-related behaviors, i.e. sitting and physical activity. The present approach differs from other mass communications and was innovative as it uses a citizen science experiment (as part of a national science event) to give tailored messages after completing a playful online survey. The aims of this unique case study were 1) to describe the process of communicating on physical activity and sitting via a citizen science experiment; 2) to evaluate the reach of the campaign; and 3) to assess the characteristics of the audience that was reached. 


\section{Method}

\section{Science event and website}

Since 2010, the public one-whole day (10AM-5PM) event, called 'Science day', is a large scale initiative of the Flemish government in which partners (museums, universities, companies) hold open house and organize science-related activities, workshops, demonstrations, readings. This yearly happening attracts $30,000-35,000$ visitors throughout Flanders (northern, Dutch-speaking part of Belgium with 6,250,000 inhabitants of which $80.6 \%$ are over 18 years old). Coordination of the event is done by Technopolis, the Flemish Science Centre, an initiative of the Flemish government to bring science and technology closer to people. Their initiatives aim to inform and raise awareness about the importance of science and technology and to increase enrolment, graduation and advancement in sciences. Godmothers and -fathers of the event are local famous personalities such as 2008 Olympics medalist Kim Gevaert. The organization of the science event is done in collaboration with the association of Flemish universities and colleges, and other partners ( $\mathrm{n}=162$ in 2015) including scientific institutions and associations, museums and interested companies. In 2015, the event took place on November 22. All information about the event is gathered on a website (http://www.dagvandewetenschap.be/; 'science day'). Since 2012, one aspect of the science event is to engage the public in a citizen science 'experiment' through an online survey. Using the taxonomy for citizen science for public health of Den Broeder et al, this citizen science mass-experiment can be classified as a mass-sized project aimed at educational goals, using a crowd sourcing approach (Den Broeder et al., 2016). A whole area of the national 'Science Day' website and communication strategy is dedicated to this citizen science mass-experiment. 


\section{Citizen science mass-experiment: online survey}

Topics of previous citizen science mass-experiments were the measurement of the speed of light (1,000 participants) and testing the memory capacity of the population through online tools $(14,139$ tests completed; tests could be done several times, number of unique users are unknown). In 2015, the citizen science mass-experiment consisted of an online survey focusing on health-related behaviors, i.e. sitting and physical activity. The content of the online survey was provided by the team of researchers in the period July-October 2015. The citizen science mass-experiment was publicly online available on October 27, 2015.

On the homepage of the science event, people were enticed to complete the citizen science mass-experiment. An introduction paragraph described that the survey was trying to find out to which totem animal (a koala, a gorilla, a zebra or a bee) the person relates to by assessing the level of sitting time and physical activity (see Table 1). The concept of totem animals was suggested by Technopolis (coordinator of the event) as a way to make the citizen science mass-experiment attractive to a broad audience. Before completing the survey, it was explained that too much sitting (more than 8 hours a day) is unhealthy because of the link with chronic diseases. In the survey (about 10 questions), participants were asked to provide their gender, age, postal code, height (non-compulsory) and weight (non-committal), and sitting (daily duration) on week- and weekend days in several domains (Marshall, Miller, Burton, \& Brown, 2010). Physical activity level was assessed with 2 questions: 1) How many times per week do you do sport for at least 20 minutes?; 2) How many times per week are you being physically active for at least 30 minutes? (answering options: not, 1-2 times per week, 3-4 times per week, >5 times per week) (Marshall, Smith, Bauman, \& Kaur, 2005). After completing the questions, participants were referred to a 'result page' and received one of four messages and their 'totem animal' (see Table 1). Questions and messages were adjusted for youth (users being $<18$ years) if they participated. However, for this study, the focus was on 
adults, so data from youth were excluded when describing the characteristics of the completers of the mass-experiment.

$\rightarrow$ Please insert table 1 near here

Web developers programmed the tailoring of the messages according to the answers given to the questions related to sitting and physical activity (see Table 1). In addition to the feedback message (e.g. You are a zebra: you don't sit too much but you move too little!), participant also received information on the health risks related with too much sitting and some tips to reduce sitting or maintain low levels of sitting time (see Table 2). Health-related guidelines for physical activity were also included and users were referred to a website promoting the '10,000 Steps'-concept (De Cocker, De Bourdeaudhuij, Brown, \& Cardon, 2007).

$\rightarrow$ Please insert table 2 near here

\section{Communication plan}

Media attention for the science event and for the citizen science mass-experiment was realized in several ways (see Table 3). Participants were encouraged to share their totem animal via social media such as Facebook and Twitter, in hope to create a viral message. However, there was no Facebook page or hashtag specifically dedicated to the citizen science massexperiment, only one for the event itself (https://nl-nl.facebook.com/DagVanDeWetenschap; \#dvdw2015). One tweet on the citizen science mass-experiment was posted by @ dagvdwetenschap ('science event') stimulating people to complete the citizen science massexperiment ("Are you sitting too much? Join the test and find it out! http://www.dagvandewetenschap.be/massa_experiment... \#dvdw2015").

$\rightarrow$ Please insert table 3 near here 


\section{Data analyses}

The spread in the digital media and use of the website and online citizen science massexperiment were analyzed using Google Analytics (web analytics service offered by Google to track and report website traffic (Crutzen, Roosjen, \& Poelman, 2013)) and Facebook graph API (Graham, 2008). Answers to the online survey were analyzed using SPSS 21.0. Descriptive statistics were calculated to describe characteristics of adults completing the citizen science mass-experiment. $\mathrm{X}^{2}$-tests were conducted to compare the four profiles across gender and adult age groups (18-39 years = young adults, 40-64 years = middle-aged adults, 65-80 years $=$ older adults $)$. Youth $(<18$ years, $n=468)$ were excluded from these analyses as the aim of this citizen science experiment was to reach and inform the adult population.

\section{Results}

\section{Website visits and completions of the online citizen science mass-experiment}

In the period before the 'science day' event (Oct 28, 2015 to Nov 21, 2015), 44,475 people visited the 'science day' website. There was $9.15 \%$ conversion, meaning that 4,071 people completed the online citizen science mass-experiment from the 'science day' website, 1,122 people visited the 'mass-experiment' page directly. The peak of the 'mass-experiment' page views $(n=5,103)$ and completions $(n=1,209)$ was reached on November 18,2015 . The day of the event (Nov 22, 2015), a total number of 5,669 individuals had completed the 'massexperiment'. During that day, $3.0 \%$ of the people visiting the website went on to complete the 'mass-experiment'. During a period after the event (Nov 23, 2015 to Jun 28, 2016), 6,219 people had visited the science day website, with a $11.4 \%$ conversion (708 people completing the survey via the main website) and 309 people completed the 'mass-experiment' directly. In the week after a newspaper article came out in a women's magazine (Jan 28, 2016), there was 
a peak of website visits from 20 per day to 50 per day. At the time of preparing the paper (May 2017), 7,329 'mass-experiments' were completed. Table 4 provides an overview of the use of the 'science day' website and online citizen science mass-experiment before and after the science event. There were 10,711 website sessions done via social referral $(16.3 \%$ of the total of 65,342 website visits), of which $91.4 \%$ were via Facebook and $8.0 \%$ via Twitter.

$\rightarrow$ Please insert table 4 near here

In Facebook, the total count of the 'koala' page was 79 (33 times shared, 38 times liked, 8 times commented), for the 'gorilla' page this was 66 (17 times shared, 22 times liked, 27 times commented), for the 'zebra' page this was 90 (28 times shared, 46 times liked, 16 times commented) and for the 'bee' page, 274 (123 times shared, 115 times liked, 36 times commented). The tweet regarding the 'mass-experiment' sent by the main organization was retweeted 6 times and liked 8 times. The tweets of the celebrities were retweeted 4 times twice and liked 6 and 2 times respectively. People retweeting and liking the tweets were mainly members or partners of the 'science day' event organization. Another 10 tweets using \#dvdw2015 were related to the 'mass-experiment'.

\section{Characteristics of completers of the online citizen science mass-experiment}

Of the adults (18+ years) completing the 'mass-experiment' $(n=6,246), 4,107$ were female (65.8\%). The average age of the participants was 37.5 (13.4) years and the average body mass index (BMI) of those providing height and weight $(\mathrm{n}=6,031)$ was $23.8(3.9) \mathrm{kg} / \mathrm{m}^{2}$. The largest proportion of the total sample was classified as a bee $(46.4 \%)$, about a quarter was classified as a koala (26.5\%), $19.1 \%$ as a zebra, and $8.0 \%$ as a gorilla. Among each profile, the majority was female, however this was most clear among the zebra's $(71.6 \%$ female vs $28.4 \%$ male), koalas ( $67.6 \%$ female vs $32.4 \%$ male) and bees ( $64.2 \%$ female vs $35.8 \%$ male) 
and less clear among the gorillas $(55.0 \%$ female and $45 \%$ male $)\left(\mathrm{X}^{2}=49.4, \mathrm{p}<0.001\right)$. There were also differences according to age $\left(\mathrm{X}^{2}=89.4, \mathrm{p}<0.001\right)$ with clearly more young adults among the gorillas (68.9\% young vs $29.3 \%$ middle-aged vs $1.8 \%$ older adults), bees $(61.7 \%$ young vs $34.8 \%$ middle-aged vs $3.5 \%$ older adults) and koalas (60.9\% young vs $37.8 \%$ middle-ages vs $1.3 \%$ older adults), while among the zebras about half of the sample were young adults ( $51.1 \%$ young vs $43.6 \%$ middle-ages vs $5.2 \%$ older adults).

The total daily average was 482.8 (143.5) minutes of sitting. A proportion of $38.1 \%$ indicated to be physically active for at least 30 minutes on minimum 5 days a week, while $21.7 \%$ reported to do sports for at least 20 minutes on minimum 3 days a week. About $4.8 \%$ reported they never engage in 30 minutes of physical activity and $34.8 \%$ never engaged in 20 minutes of sports.

\section{Discussion}

The present paper describes the process of communicating a health-related topic to a broad audience via a citizen science experiment organized during a well-established yearly national science event day. The occurrence of this event was considered an opportunity to increase the reach of a mass media campaign about physical activity and sitting. Playful online messages on this topic were used to increase appeal and deliver the message by stealth (use of animal totem) among those completing the citizen science mass-experiment. Communication to the public about important health-related behaviors is warranted to inform, influence and motivate public audiences, in order to advance public health (Lankford et al., 2014; Leavy et al., 2011). Furthermore, awareness of guidelines concerning health-behaviors, including physical activity and especially sitting, should be increased (De Cocker et al., 2015; Hunter et al., 2014; Kay et al., 2014; LeBlanc et al., 2015). The aims here were to find out if and how a 
broad audience was reached with the mass-experiment delivered as part of a well-known national science event and what the characteristics of the reached population are.

Results indicate that making use of a citizen science experiment linked to a national science event is a good opportunity to communicate about health-topics such as sitting and physical activity. Assuming a population of about 5,037,500 adult citizens in Flanders, the 'science day' website was visited by $1.3 \%$ of the entire population. Half of them $(0.6 \%)$ visited the citizen science mass-experiment page and about one in thousand (0.1\%) Flemish adults completed this citizen science mass-experiment. Compared to other mass-reach campaigns, the present numbers are substantial. Population reach for three years of online tobacco cessation media campaigns ranged from $1.8-2.2 \%$ of tobacco users in Florida, $1.7 \%$ in New York and $0.8 \%$ in California (Duke et al., 2014). The present communication campaign of a couple of months was only focused around a one-day event, and could reach a considerable part of the population. The comparison with the previous American study may suggest that there is room for improvement: if the playful citizen science mass-experiment would be promoted for a longer time, possibly more citizens could be reached. In addition, for the 'science day' event, only one press conference was organized. This type of communication strategy is always at risk to compete with other unforeseen catastrophic or political events which attract attention of media and public. It is not clear whether the terrorist attacks in Paris in November 2015 which got a lot of media attention, had an impact on the present success. The communication on the health topics were organized around a national science event, as this could provide a broad support for the spread of the playful messages. It should be noted that the science event day itself did not result in the majority of the citizen science massexperiment completions $(n=476)$, nor did the period after the event $(n=686$ in total; average of 27 per day). In the period before the event, most mass-experiments were completed ( $n=5,193$; 
average of 200 per day), which may probably be explained by the fact that most of the promotion for the mass-experiment was done in this period. The conversion rates leading people from the science day website to the mass-experiment were higher during the period before (9.2\%) and after (11.4\%) the event than on the day itself $(3.0 \%)$.

About $16.4 \%$ of the website visits were done via social referrals which was mainly via Facebook. The referral rate may seem rather low, however it should be noted that there was no direct link on social media or no specific twitter feed or hashtag of the mass-experiment, which should be recommended for future citizen science mass-experiments. The Facebook counts of the pages with the mass-experiment results were mostly registered via likes $(43.4 \%)$ and shares $(39.5 \%)$, less via comments $(17.1 \%)$. The retweets and likes of the tweets of the organization and celebrities were low and mostly deriving from associates of the organization. This may suggest that the online citizen science mass-experiment did not go viral on social media and that the setting of the science day event including the mass-experiment was sufficient to reach the population.

A second aim was to find out who completed the online citizen science mass-experiment. These adults were mainly (65.8\%) female, on average 38 years old and had a healthy weight status. Compared to all Flemish adults $\left(50.7 \%\right.$ female; average BMI of $\left.25.3 \mathrm{~kg} / \mathrm{m}^{2}\right)$, this sample includes more women and has a better weight status (Drieskens, 2014). The referral to the mass-experiment in a women's magazine may be an explanation for the high number of women completing the survey. However, this article was published several months after the science day event. Also the proportion individuals engaging in sufficient physical activity level was better here (38\%) compared to that of a Flemish sample (28\%) (Drieskens, 2014). For sitting, the present sample ( 8.1 hours/day, self-reported) seems to be comparable to the Flemish population (8.3 hours/day, accelerometer-based) (Spittaels et al., 2012). Regarding 
the profiles, the present sample also had better results compared to a Flemish working population in which $31.0 \%$ had the least healthy profile (high sitting and low physical activity), 20.7\% combined low sitting with low physical activity, 15.1\% combined high sitting with high physical activity and 33.2\% had the most beneficial profile (low sitting and high physical activity) (De Cocker, Seghers, \& Cardon, 2015). The present proportions were respectively $26.5 \%, 19.1 \%, 8.0 \%$ and $46.4 \%$. This may suggest that the present massexperiment was mostly attractive to people already engaging in physical activity. Other approaches seem to be needed in order to reach less active individuals. Previous research revealed that people misperceiving their physical activity level do not pay attention to health messages about physical activity because they think these messages do not apply to them (Bolman, Lechner, \& van Dijke, 2007). Future citizen science events or experiments could find out whether even more stealth messages (having other animals or something else as dominating feature) would attract more people not usually interested in physical activity and sitting. In addition, more at-risk populations might be reached if this communication tool would be spread by other channels such as local health workers, general practitioners or via citizen science communication more directly targeted at them. There are indications that visuals (compared with text-based messages) can be an effective strategy in increasing selfefficacy for health behaviors (Chang, 2013) and that group pictures show to have greater impact to improve high-risk populations' attitude, self-efficacy and intentions to engage in physical activity compared to pictures depicting a single physically active individual (Reifegerste \& Rossmann, 2017). Similar studies studying message framing of sedentary behavior are currently missing.

A weakness in the development of the citizen science experiment is the arbitrary selection of the animal totems. No formative research around the development and pre-testing of these 
profile were conducted. It is consequently unknown whether the choice of the animals was appealing to the general adult population. One could think that this approach is more appealing to individuals younger than 18 years. Although this was not the target group of the citizen science experiment, the reach of children and adolescents was substantial lower $(n=468)$ compared to the reach of adults $(n=6,686)$. Another limitation is the fact that we did not reach a sample representative of the Flemish population. However, one should note that surveillance or monitoring was not the purpose of the citizen science mass-experiment, which was originally designed to increase knowledge and awareness on sitting and physical activity. Nonetheless, epidemiology is gradually becoming a discipline in which digital sources of information (from mobile phones and Internet usage) are becoming more important to collect data (Salathe et al., 2012), but then recruitment (random recruitment instead of volunteering samples) and behavioral assessment (objective measures instead of self-reported data which is vulnerable for social desirability biases) should be done different than the methods used here.

\section{Conclusion}

It can be assumed that a well-established citizen science experiment is a good platform for stealth health communication. A substantial amount of adults could be reached, especially before the event. However, the citizen science experiment did not seem to reach a representative sample in terms of demographics or physical activity levels. The level of sitting time appeared to be comparable to that reported in other Flemish studies, but completers of the citizen science mass-experiment were more physically active than the Flemish population. Further research can examine whether such citizen science events have a higher reach when coupled with a stronger branded social media campaign or when using other dominating playful features. 


\section{List of abbreviations}

API: application programming interface

BMI: body mass index

CVD: cardiovascular disease

METs: metabolic equivalents

\section{Ethics approval and consent to participate}

The study protocols were approved by the Ethics Committee of the Ghent University Hospital, Belgium (2012_320; IRB registration number B670201214227). Informed consent was obtained from all participants.

\section{Consent for publication}

Not applicable.

\section{Availability of data and materials}

The dataset supporting the conclusions of this article is included as an additional file.

\section{Competing interests}

There are no potential, perceived, or real conflicts of interest related to the research reported in the manuscript. All authors agree with the content of the manuscript and no author has interest that might be interpreted as influencing the research.

\section{Funding}

K.D.C. was supported by the Research Foundation Flanders (FWO) (postdoctoral research fellowship: FWO11/PDO/097). 


\section{Authors' contribution}

K.D.C. wrote the first draft of the manuscript and led the writing of the paper. K.D.C., S.C. and G.C. contributed to the conception and designing of the study, the statistical analyses and interpretation of the data. S.C., I.I. and G.C. provided substantial feedback on the manuscript.

\section{Acknowledgements}

The authors want to acknowledge Technopolis and their partners for the organisation of the mass-experiment, and 2dotstwice, the web developers of the online survey. We would also like to thank the participants for providing the data. The content of this paper reflects the authors' views only.

\section{References}

Bolman, C., Lechner, L., \& van Dijke, M. (2007). Question order in the assessment of misperception of physical activity. International Journal of Behavioral Nutrition and Physical Activity, 4, 42. doi:10.1186/1479-5868-4-42

Chang, C. (2013). Seeing is believing: The direct and contingent influence of pictures in health promotion advertising. Health Communication, 28, 822-834. doi:10.1080/10410236.2012.726403

Crutzen, R., Roosjen, J. L., \& Poelman, J. (2013). Using Google Analytics as a process evaluation method for internet-delivered interventions: An example on sexual health. Health Promotion International, 28, 36-42. doi:10.1093/heapro/das008

De Cocker, K., Seghers, J., \& Cardon, G. (2015). Fysieke activiteit - zitten: Fysieke actieve en sedentaire tijdsbesteding bij de Vlaamse bevolking. In J. S. Lievens \& H. Waege 
(Eds.), Participatie in Vlaanderen 2: Eerste analyses van de participatiesurvey 2014 (pp. 283-295). Leuven, Belgium: Acco.

De Cocker, K., Veldeman, C., De Bacquer, D., Braeckman, L., Owen, N., Cardon, G., \& De Bourdeaudhuij, I. (2015). Acceptability and feasibility of potential intervention strategies for influencing sedentary time at work: Focus group interviews in executives and employees. International Journal of Behavioral Nutrition and Physical Activity, 12, 22. doi:10.1186/s12966-015-0177-5

De Cocker, K. A., De Bourdeaudhuij, I. M., Brown, W. J., \& Cardon, G. M. (2007). Effects of "10,000 steps Ghent": A whole-community intervention. American Journal of Preventive Medicine, 33, 455-463. doi:10.1016/j.amepre.2007.07.037

Den Broeder, L., Devilee, J., Van Oers, H., Schuit, A. J., \& Wagemakers, A. (2016). Citizen science for public health. Health Promotion International. doi:10.1093/heapro/daw086

Drieskens, S. (2014). Lichaamsbeweging. In L. Gisle \& S. Demarest (Eds.), Gezondheidsenquete 2013. Rapport 2: Gezondheidsgedrag en leefstijl. Brussel, Belgium: WIV-ISP.

Duke, J. C., Mann, N., Davis, K. C., MacMonegle, A., Allen, J., \& Porter, L. (2014). The impact of a state-sponsored mass media campaign on use of telephone quitline and web-based cessation services. Preventing Chronic Disease, 11, E225. doi:10.5888/pcd11.140354

Follett, R., \& Strezov, V. (2015). An analysis of citizen science based research: Usage and $\begin{array}{llll}\text { publication } & \text { patterns. } & \text { PLOS } & \text { ON }\end{array}$ doi:10.1371/journal.pone.0143687

Graham, A. (2008). Facebook API developers guide. New York, NY: Apress. 
Haskell, W. L., Lee, I. M., Pate, R. R., Powell, K. E., Blair, S. N., Franklin, B. A., . . . Bauman, A. (2007). Physical activity and public health: Updated recommendation for adults from the American College of Sports Medicine and the American Heart Association. Medicine and Science in Sports and Exercise, 39. doi:10.1249/mss.0b013e3180616b27

Hunter, R. F., Tully, M. A., Donnelly, P., Stevenson, M., \& Kee, F. (2014). Knowledge of UK physical activity guidelines: Implications for better targeted health promotion. Preventive Medicine, 65, 33-39. doi:10.1016/j.ypmed.2014.04.016

Kay, M. C., Carroll, D. D., Carlson, S. A., \& Fulton, J. E. (2014). Awareness and knowledge of the 2008 Physical Activity Guidelines for Americans. Journal of Physical Activity and Health, 11, 693-698. doi:10.1123/jpah.2012-0171

Lankford, T., Wallace, J., Brown, D., Soares, J., Epping, J. N., \& Fridinger, F. (2014). Analysis of physical activity mass media campaign design. Journal of Physical Activity and Health, 11, 1065-1069. doi:10.1123/jpah.2012-0303

Leavy, J. E., Bull, F. C., Rosenberg, M., \& Bauman, A. (2011). Physical activity mass media campaigns and their evaluation: A systematic review of the literature 2003-2010. Health Education Research, 26, 1060-1085. doi:10.1093/her/cyr069

LeBlanc, A. G., Berry, T., Deshpande, S., Duggan, M., Faulkner, G., Latimer-Cheung, A. E., . . . Tremblay, M. S. (2015). Knowledge and awareness of Canadian Physical Activity and Sedentary Behaviour Guidelines: A synthesis of existing evidence. Applied Physiology Nutrition and Metabolism, 40, 716-724. doi:10.1139/apnm-2014-0464

Marshall, A. L., Miller, Y. D., Burton, N. W., \& Brown, W. J. (2010). Measuring total and domain-specific sitting: A study of reliability and validity. Medicine and Science in Sports and Exercise, 42, 1094-1102. doi:10.1249/MSS.0b013e3181c5ec18 
Marshall, A. L., Smith, B. J., Bauman, A. E., \& Kaur, S. (2005). Reliability and validity of a brief physical activity assessment for use by family doctors. British Journal of Sports Medicine, 39, 294-297. doi:10.1136/bjsm.2004.013771

McGuire, W. J. (2001). Input and output variables currently promising for constructing persuasive communications. In R. Rice \& C. K. Atkin (Eds.), Public communication campaigns (pp. 22-48). Thousand Oaks, CA: SAGE Publications

Reifegerste, D., \& Rossmann, C. (2017). Promoting physical activity with group pictures. Affiliation-based visual communication for high-risk populations. Health Communication, 32, 161-168. doi:10.1080/10410236.2015.1110007

Robinson, M. N., Tansil, K. A., Elder, R. W., Soler, R. E., Labre, M. P., Mercer, S. L., . . . Community Preventive Services Task, F. (2014). Mass media health communication campaigns combined with health-related product distribution: A community guide systematic review. American Journal of Preventive Medicine, 47, 360-371. doi:10.1016/j.amepre.2014.05.034

Salathe, M., Bengtsson, L., Bodnar, T. J., Brewer, D. D., Brownstein, J. S., Buckee, C., . . . Vespignani, A. (2012). Digital epidemiology. PLOS Computational Biology, 8(7), e1002616. doi:10.1371/journal.pcbi.1002616

Spittaels, H., Van Cauwenberghe, E., Verbestel, V., De Meester, F., Van Dyck, D., Verloigne, M., . . . De Bourdeaudhuij, I. (2012). Objectively measured sedentary time and physical activity time across the lifespan: A cross-sectional study in four age groups. International Journal of Behavioral Nutrition and Physical Activity, 9, 149. doi:10.1186/1479-5868-9-149

Thorp, A. A., Owen, N., Neuhaus, M., \& Dunstan, D. W. (2011). Sedentary behaviors and subsequent health outcomes in adults a systematic review of longitudinal studies, 
1996-2011. American Journal of Preventive Medicine, 41, 207-215. doi:10.1016/j.amepre.2011.05.004 
Table 1: Overview of the four profiles

\begin{tabular}{|c|c|c|c|}
\hline \multirow[t]{2}{*}{ Profile } & \multirow[t]{2}{*}{ Picture } & \multicolumn{2}{|c|}{ Profile characteristics and main message } \\
\hline & & Sport/physical activity & Sitting \\
\hline \multirow[t]{2}{*}{ Koala } & & $\begin{array}{l}\text { Less than } 2 \text { times/week sports for } \\
\text { at least } 20 \text { minutes } \\
\text { AND } \\
\text { Less than } 4 \text { times/week being } \\
\text { physically active for at least } 30 \\
\text { minutes }\end{array}$ & $\begin{array}{l}\text { More than } 480 \text { minutes of } \\
\text { sitting per day [19] }\end{array}$ \\
\hline & & \multicolumn{2}{|c|}{ Message: You are a koala: you sit too much and move too little! } \\
\hline \multirow[t]{2}{*}{ Gorilla } & & $\begin{array}{l}\text { At least } 3 \text { times/week sports for at } \\
\text { least } 20 \text { minutes } \\
\text { OR } \\
\text { At least } 5 \text { times/week being } \\
\text { physically active for at least } 30 \\
\text { minutes }\end{array}$ & $\begin{array}{l}\text { More than } 480 \text { minutes of } \\
\text { sitting per day [19] }\end{array}$ \\
\hline & & \multicolumn{2}{|c|}{ Message: You are a gorilla: you sit too much but you move enough! } \\
\hline \multirow[t]{2}{*}{ Zebra } & & $\begin{array}{l}\text { Less than } 2 \text { times/week sports for } \\
\text { at least } 20 \text { minutes } \\
\text { AND } \\
\text { Less than } 4 \text { times/week being } \\
\text { physically active for at least } 30 \\
\text { minutes }\end{array}$ & $\begin{array}{l}\text { Less than } 480 \text { minutes of } \\
\text { sitting per day [19] }\end{array}$ \\
\hline & & \multicolumn{2}{|c|}{$\begin{array}{l}\text { Message: You are a zebra: you don't sit too much but you move too } \\
\text { little! }\end{array}$} \\
\hline Bee & & $\begin{array}{l}\text { At least } 3 \text { times/week sports for at } \\
\text { least } 20 \text { minutes } \\
\text { OR } \\
\text { At least } 5 \text { times/week being } \\
\text { physically active for at least } 30 \\
\text { minutes }\end{array}$ & $\begin{array}{l}\text { Less than } 480 \text { minutes of } \\
\text { sitting per day [19] }\end{array}$ \\
\hline & & \multicolumn{2}{|c|}{$\begin{array}{l}\text { Message: You are a bee: you don't sit too much and you move } \\
\text { enough! }\end{array}$} \\
\hline
\end{tabular}


Table 2: Content of the additional messages

\begin{tabular}{|c|c|}
\hline Don't sit too much & $\begin{array}{l}\text { Too much sitting increases the risk of having health disorders, such as } \\
\text { diabetes, coronary heart diseases, certain cancers and premature } \\
\text { death. How much is too much? Eight hours sitting per day is the } \\
\text { recommended maximum. Below you find some tips to sit less: } \\
\text { - Replace sitting activities by activities of light intensity such } \\
\text { as standing or walking } \\
\text { - Keep standing while waiting at the bus or waiting room } \\
\text { - Walk while being on the phone } \\
\text { - Having a job? Keep standing during breaks or during a } \\
\text { conversation with colleagues }\end{array}$ \\
\hline Don't sit too long & $\begin{array}{l}\text { It's not only good to sit less, it's also good to sit for less longer } \\
\text { periods. Uninterrupted sitting changes our physiology and is therefore } \\
\text { bad for our health. Break up periods of uninterrupted sitting by } \\
\text { standing up or walking around. One break every } 30 \text { minutes can do a } \\
\text { lot! Here are some tips on how to break up your sitting: } \\
\text { - Get up to drink something } \\
\text { - Commercials in TV? Get up and walk around for a minute } \\
\text { - Set an alarm (on your phone) that reminds you of a break } \\
\text { from sitting. }\end{array}$ \\
\hline $\begin{array}{lll}\text { Physical activity and } \\
\text { sport }\end{array}$ & $\begin{array}{l}\text { To further improve your health, be active for at least } 5 \text { times a week } \\
\text { during } 30 \text { minutes, or sport for at least three time a week during } 20 \\
\text { minutes. Check www. } 10000 \text { stappen.be for more tips to become/stay } \\
\text { active. }\end{array}$ \\
\hline
\end{tabular}


Table 3: Communication plan

\begin{tabular}{|c|c|c|}
\hline Engagement strategy & Message & $\begin{array}{l}\text { Timeline } \\
\text { (number \& } \\
\text { frequency) }\end{array}$ \\
\hline $\begin{array}{l}\text { Use of social media } \\
\text { from celebrities: } \\
\text { celebrity endorsement }\end{array}$ & $\begin{array}{l}\text { Invitation to complete the online citizen science mass- } \\
\text { experiment: } \\
\text { Are you sitting too much? Join the mass-testing of } \\
\text { @dagvdwetenschap: } \\
\text { http://www.radiol.be/node/421057 \#hautekiet } \\
\text { Join the mass-testing of the "Science day" on } \\
\text { http://www.dagvandewetenschap.be/massa_experiment ... }\end{array}$ & $\begin{array}{l}\text { One tweet of } 2 \\
\text { celebrities } \\
\text { (Nov } 4 \& 18 \text {, } \\
2015 \text { ) }\end{array}$ \\
\hline $\begin{array}{l}\text { Interviews on } \\
\text { broadcast media from } \\
\text { celebrities: celebrity } \\
\text { endorsement }\end{array}$ & $\begin{array}{l}\text { Invitation to complete the online citizen science mass- } \\
\text { experiment }\end{array}$ & $\begin{array}{l}\text { One with } 2 \\
\text { celebrities } \\
\text { (Nov } 17 \& 18, \\
2015\end{array}$ \\
\hline $\begin{array}{l}\text { Radio advertisements } \\
\text { with celebrities on } \\
\text { popular radio stations: } \\
\text { celebrity endorsement }\end{array}$ & $\begin{array}{l}\text { Invitation to complete the online citizen science mass- } \\
\text { experiment }\end{array}$ & $\begin{array}{l}242 \\
\text { advertisements } \\
\text { of } 10 \text { or } 30 \\
\text { seconds during } \\
2 \text { weeks }\end{array}$ \\
\hline $\begin{array}{l}\text { Advertisement in } \\
\text { printed press }\end{array}$ & $\begin{array}{l}\text { Invitation to complete the online citizen science mass- } \\
\text { experiment }\end{array}$ & $\begin{array}{l}\text { One in } 3 \\
\text { weekend press } \\
\text { (Nov 21, 2015) }\end{array}$ \\
\hline $\begin{array}{l}\text { Online advertisement } \\
\text { on University and } \\
\text { press websites }\end{array}$ & Invitation to the event & $\begin{array}{l}\text { Three on } 2 \\
\text { websites } \\
\text { (Oct } 29, \text { Nov } \\
12, \& 17, \\
2015 \text { ) }\end{array}$ \\
\hline $\begin{array}{l}\text { Direct contact with } \\
\text { previous attendee } \\
\text { (Technopolis) }\end{array}$ & Invitation to the event & $\begin{array}{l}\text { Nov 12-17, } \\
2015\end{array}$ \\
\hline Press conference & $\begin{array}{l}\text { Invitation to the event and completing of the online citizen } \\
\text { science mass-experiment }\end{array}$ & $\begin{array}{l}\text { One on Nov } \\
17,2015\end{array}$ \\
\hline
\end{tabular}


Table 4: Website and online citizen science mass-experiment use

\begin{tabular}{|l|c|c|c|c|}
\hline \multirow{2}{*}{ Date } & \multicolumn{2}{|c|}{ Whole website } & \multicolumn{2}{c|}{$\begin{array}{c}\text { Online citizen science mass- } \\
\text { experiment }\end{array}$} \\
\cline { 2 - 5 } & Visits & New users & Visits & Completions \\
\hline Nov 17, 2015 (press conference) & 4,299 & $77.6 \%$ & 1,740 & 360 \\
\hline Nov 22, 2015 (day of event) & 12,510 & $69 \%$ & 2,813 & 476 \\
\hline Nov 28, 2015 & 114 & $43 \%$ & 66 & 13 \\
\hline Oct 27, 2015- June 28, 2016 & 65,342 & $70.8 \%$ & 31,109 & 6,686 \\
\hline
\end{tabular}

